\title{
In stored human blood, the inhibitor effect of tannic acid and caffeic acid on lipid peroxidation and oxidative DNA damage
}

\author{
Zübeyir Huyut ${ }^{1, *}$, Mehmet Ramazan Şekeroğlư ${ }^{2}$, Ragıp Balahoroğlu ${ }^{1}$, Hamit Hakan Alp ${ }^{1}$, Erdem \\ Çokluk ${ }^{1}$
}

${ }^{1}$ Department of Medical Biochemistry, Yuzuncu Yil University Faculty of Medicine, Van, Turkey

${ }^{2}$ Department of Medical Biochemistry, Sakarya University Faculty of Medicine, Sakarya, Turkey

\begin{abstract}
Stored bloods, are exposed to a number of negative changes called as "storage lesions" morphological, biochemical and functional, to begin the first phase of the storage. In this study, we investigated the effects of caffeic and tannic acid in lipid peroxidation and oxidative DNA damage in stored blood.

The blood was taken from 10 healthy male individuals to the blood bag containing CPD. Each donor's blood was separated into three groups. The first group was used as the control group with nothing added to the blood. A total of $30 \mu \mathrm{g} / \mathrm{mL}$ caffeic acid and $15 \mu \mathrm{g} / \mathrm{mL}$ tannic acid was added to the second and third group, respectively. Malondialdehyde, ubiquinone-10 and 8-hydroxy-2 deoxyguanosine levels were determined at baseline and on the $7^{\text {th }}, 14^{\text {th }}, 21^{\text {st }}$ and $28^{\text {th }}$ day, by high pressure liquid chromatography.

The MDA and 8-OHdG levels of control and tannic acid groups were increased on the $21^{\text {st }}$ and $28^{\text {th }}$ days $(\mathrm{p}<0.001)$, whereas in caffeic acid group was preserved. Also, CoQ10 levels increased in the control group time dependently $(\mathrm{p}<0.001)$, but preserved in the other two groups. In addition, CoQ10 and 8-OHdG levels of tannic and especially caffeic acid groups was lower than the control group in the inter-group comparison, in periods of progressing time $(\mathrm{p}<0.05)$.

These results showed that oxidative stress increased in the stored blood, but adding tannic and caffeic acid into the stored blood can attenuate the effects of oxidation.
\end{abstract}

Key Words: Antioxidant, oxidative DNA damage, storage lesions, stored blood, peroxidation

\section{Introduction}

Globally, approximately 80 million units of blood are donated in each year (1). At the end of 2015, about 2 million units of blood are collected by the Turkish Red Cresent in Turkey (2). Currently, storage procedures of blood bags in the blood banks, to support a healthy and safe blood is required for conditions that guarantee the maximized storage time. Stored bloods can be retained at $2-6{ }^{\circ} \mathrm{C}$ for up to a month at present. There are two criteria determined for maximum storage period. These criterias; during the storage period rate of hemolysis in erythrocytes should not exceed $1 \%$ and after the transfusion at least $75 \%$ of RBCs should stay alive in the first 24 hours (3). In many clinical situation, blood transfusion is necessary, such as deep anemia, acute blood loss and some surgeries $(4,5)$. Several studies indicated that while the stored blood maintained at optimum conditions, some adverse change occurs called as "storage lesion" time-dependently. These are increase of lipid peroxidation, decrease of antioxidant capacity and some morphological change in the blood components (6,7). Some antioxidants or metal binding chelators are adding to minimize these undesirable changes and increase the effectiveness of preservative solutions (6). Tannic acid and caffeic acid are phenolic compounds which are commonly found in our daily diet (8-10). The antioxidant activity of phenolic compounds is mainly attributed to their redox properties, which allow them to act as reducing agents, hydrogen donors and quenchers of singlet oxygen. In addition, they may also possess metal chelation properties (10).

Tannic acid is a naturally occurring polyphenol compound found largely in the fruits and vegetables, such as; pear, banana, cowpea, lentil and black tea and also found in chocolate, wine, beer and coffee (1012). Gülçin et al. (10) repoted that $15 \mu \mathrm{g} / \mathrm{mL}$ concentration of tannic acid inhibit peroxidation of linoleic acid emulsion $97.7 \%$. In addition, it has scavenging activity of free radicals such as 1,1diphenyl-2-picryl-hydrazyl free radical (DPPH), 2,20azino-bis(ABTS), superoxide anion and chelation 
capacity of ferrous ions $\left(\mathrm{Fe}^{2+}\right)$, hydrogen peroxide scavenging.

Caffeic acid and its derivatives are good substrates of polyphenol oxidases, and under certain condition may undergo oxidation. It has been reported that Caffeic acid (3,4-dihydroxycynnamic acid) act as the protective of $\alpha$-Tocopherol in low density lipoproteins (13). Gülçin (9) has reported that caffeic acid inhibited peroxidation of linoleic acid emulsion in samples $75.8 \%$ added $30 \mu \mathrm{g} / \mathrm{mL}$ caffeic acid. In addition, caffeic acid is an effective ABTS scavenging, DPPH scavenging, superoxide anion radical scavenging, total reducing power and metal chelating on ferrous ions activities (9). Also, the most antioxidant effect of caffeic and tannic acid is at 30 and $15 \mu \mathrm{g} / \mathrm{mL}$ concentrations as in vitro, respectively $(9,10)$.

There is no literature on the antioxidant effects of caffeic and tannic acid in stored blood. In this study we investigated the effects of caffeic and tannic acid on lipid peroxidation, mitochondrial membrane damage and oxidative DNA damage in the stored blood.

\section{Materials and Methods}

The study protocol was carried out in accordance with Helsinki decleration as revised in 2000. The study was also approved by Ethics Committee of the Clinical Drug Applications, Faculty of Medicine, Yuzuncu Yil University (date: 13.08.2014 and number of decision: 05) and all patients gave informed consent.

Blood Sampling: Blood was collected into

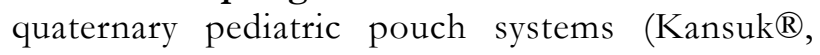
Turkey) containing citrate-phosphate-dextrose (CPD) from 10 healthy volunteers. Blood pouches contained $500 \mathrm{~mL}$ blood and each of $70 \mathrm{~mL}$ CPD $(0,299$ citric acid anhydrate, $2.63 \mathrm{~g}$ sodium citrate dihydrate, $0.222 \mathrm{~g}$ sodium dihydrogen phosphate monohydrate and $2.55 \mathrm{~g}$ dextrose monohydrate). Each $500 \mathrm{~mL}$ bag was transferred into three 150 $\mathrm{mL}$ pediatric bags. One of the bags was used as control, while the others were added with either tannic acid $(15 \mu \mathrm{g} / \mathrm{mL})$ or caffeic acid $(30 \mu \mathrm{g} / \mathrm{mL})$ and denoted as tannic acid and caffeic acid groups. The bloods were then stored at $+4{ }^{\circ} \mathrm{C}$. Before taking samples the bags were gently turned upside down to homogenize the stored blood. Six milliliters of blood was taken from each bag and four milliliters centrifuged $(1100 \mathrm{rpm})$ and the plasma was obteined to measure plasma malondialdehyde (MDA), ubiquinone-10 (CoQ10) levels and two milliliters of whole blood was separated for DNA 8-hydroxy-2 deoxyguanosine
(8-OHdG) measurement at the beginning (day 0) and on days $7,14,21,28$ by high pressure liquid chromatography (HPLC).

\section{Plasma MDA measurements by High Pressure} Liquid Chromatography (HPLC): MDA measurement in plasma was performed according to the method of Khoschsor et al. (14). Plasma MDA measurements by High Pressure Liquid Chromatography (HPLC): A total of $0.44 \mathrm{~mol} / \mathrm{L}$ $\mathrm{H}_{3} \mathrm{PO}_{4}$ and $42 \mathrm{mmol} / \mathrm{L}$ thiobarbituric acid (TBA) was added to $50 \mu \mathrm{L}$ plasma and incubated for 60 minutes in boiling water. After rapid cooling with icy water, an equal volume of alkaline methanol was added to the samples. After centrifugation at $3000 \mathrm{rpm}$ for 3 minutes, the supernatant was

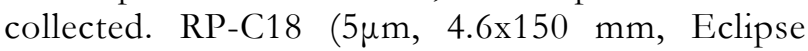
VDB-C18 Agilent) columns were used. For elution, the mobile phase volume was prepared as a 40:60 ratio with methanol and $50 \mathrm{mmol} / \mathrm{L}$ phosphate buffer. The flow rate was adjusted to $0.8 \mathrm{~mL} /$ minute a total of $20 \mu \mathrm{L}$ supernatant was loaded onto the device and measured at $527 \mathrm{~nm}$ excitation and $551 \mathrm{~nm}$ emission wavelength by HPLC using a fluorescent detector (FLD). MDATBA product peaks were calibrated with 1,1,3,3Tetraethoxypropane standard solution. The obtained results are expressed as $\mu \mathrm{M}$.

Oxide CoQ10 Analysis: Oxidized CoQ10 analysis was performed according to the method by Littarru et al. (15) The reductive CoQ10 was forced to oxidize in plasma samples treated with para-benzoquinone following extraction with 1propanol directly injected into the HPLC device. For HPLC analysis, a reverse-phase ODS supercoil C-18 $(15 \times 0.46 \mathrm{~cm}$ i.d. $3 \mu \mathrm{m})$ column was used. For analysis, $50 \mu \mathrm{L}$ 1,4-benzoquinone (2 $\mathrm{mg} / \mathrm{mL}$ ) was added to $200 \mu \mathrm{L}$ plasma and mixture was vortexed. After 10 minutes incubation at room temperature, $1 \mathrm{~mL}$ n-propanol was added, and the mixture was vortexed during $10 \mathrm{sec}$. It was centrifuged at $600 \mathrm{~g}$ for 2 minutes. A total of $200 \mu \mathrm{L}$ was collected from the supernatant, put into a vial and loaded onto the HPLC device. For spectral analysis, the UV detector was adjusted to $275 \mathrm{~nm}$, and the ethanol-methanol $(65-35 \% \mathrm{v} / \mathrm{v})$ mobile phase flow rate was adjusted to 1 $\mathrm{mL} / \mathrm{minute}$. The system was stabilized after balancing the column, and oxidized CoQ10 was measured by the electrochemical detector adjusted to $0.35 \mathrm{~V}$. The obtained results are expressed as $\mu \mathrm{M}$.

Isolation and Hydrolysis of DNA: DNA was isolated from whole blood leukocytes by DNA isolation kit (Vivantis GF-1 blood DNA extraction kit, Vivantis Technologies SDN. BHD, 
Malaysia) with the spin column method. $200 \mu \mathrm{L}$ blood sample was placed in the microcentrifuge tube and solutions were added according to the kit prospectus solution, respectively. As a result of isolation carried out in accordance to the kit prospectus, final volume was $100 \mu \mathrm{L}$. DNA aliquots were thawed for $8-\mathrm{OHdG}$ analysis and hydrolysed as previously described by Kaur and Halliwell (1996) (16). Hydrolysed DNA samples were dissolved in HPLC elution buffer (final volume, $1 \mathrm{~mL}$ ). 8-OHdG levels were measued by HPLC using EC detector. A total of $20 \mu \mathrm{L}$ final hydrolysate was measured by HPLC using ECD. Reverse-phase-C-18 (RP-C18) analytical columns $(250 \mathrm{~mm} \times 4.6 \mathrm{~mm} \times 4.0 \mu \mathrm{m}$, Phenomenex, CA) were used. The mobile phase was $0.05 \mathrm{M}$ potassium phosphate buffer ( $\mathrm{pH}$ 5.5) and acetonitrile mixture $(97: 3, \mathrm{v} / \mathrm{v})$, and the flow rate was adjusted to $1 \mathrm{~mL} / \mathrm{min}$. The levels of $8-\mathrm{OHdG}$ were measured by HPLC with the ECD adjusted to $600 \mathrm{mV}$. The obtained sample peaks were calibrated with the 8-OHdG standard purchased from Sigma Aldrich Company (Sigma diagnostics, St. Louis, MO, USA). The $8-\mathrm{OHdG}$ values were expressed as $\mu \mathrm{M}$ (17).

Statistical Analysis: Results are represented as Mean \pm Standard Error of Mean (SE). Values between the groups were analyzed by two-way ANOVA. Following variance analysis, the Duncan multiple range test was performed to identify different groups and Friedman analysis was performed to assess for significant differences on a continuous dependent variable in measuring periods. Statistical analysis was performed using the SPSS 15 statistics package program (SPSS Inc., IL, USA).

\section{Results}

The MDA levels of control group and tannic acid groups were significantly higher on $21^{\text {st }}$ and $28^{\text {th }}$ day than baseline $(p<0.001)$. However, there was no significant difference in the caffeic acid group (Table 1).

Oxidized CoQ10 which is an indicator of mitochondria membrane damage levels, were not changed in tannic and caffeic acid groups, whereas increased in the control group $(\mathrm{p}<0.001)$, on the $21^{\text {st }}$ and $28^{\text {th }}$ days (Table 2 ). The oxidized CoQ10 level of tannic and caffeic acid groups was significantly decreased in stored blood on the $21^{\text {st }}$ and $28^{\text {th }}$ days compared to the baseline in the control group $(\mathrm{p}<0.001)$. In addition, oxidized CoQ10 level of caffeic acid group was significantly lower compared to the control and tannic acid groups on the $14^{\text {th }}$ and $28^{\text {th }}$ days $(\mathrm{p}<0.001)$.

Table 1. The effect of tannic acid and caffeic acid on MDA levels in stored blood

\begin{tabular}{lccc}
\hline \multicolumn{3}{c}{ MDA $(\mu \mathrm{M})$} \\
\hline Days & Control $($ Mean \pm SE) & Tannic Acid $($ Mean \pm SE) & Caffeic Acid (Mean \pm SE) \\
\hline Baseline & $1.209 \pm 0.345$ & $1.219 \pm 0.257$ & $1.217 \pm 0.208$ \\
$7^{\text {th }}$ day & $1.381 \pm 0.168$ & $1.250 \pm 0.286$ & $1.282 \pm 0.280$ \\
$14^{\text {th }}$ day & $1.381 \pm 0.271$ & $1.479 \pm 0.171$ & $1.331 \pm 0.222$ \\
$21^{\text {st }}$ day & $1.711 \pm 0.370^{*}$ & $1.610 \pm 0.281^{*}$ & $1.400 \pm 0.336$ \\
$28^{\text {th }}$ day & $1.849 \pm 0.289^{*}$ & $1.763 \pm 0.346^{*}$ & $1.444 \pm 0.335$ \\
\hline
\end{tabular}

"*" Compared to baseline in intragroup $(\mathrm{p}<0.001)$

Table 2. The effects of tannic and caffeic acid on the level of oxidized CoQ10.

\begin{tabular}{lccc}
\hline \multicolumn{3}{c}{ CoQ10 $(\mu \mathrm{M})$} \\
\hline Days & Control $($ Mean \pm SE) & Tannic Acid $($ Mean \pm SE) & Caffeic Acid (Mean \pm SE) \\
\hline Baseline & $1.947 \pm 0.533$ & $1.888 \pm 0.282$ & $1.934 \pm 0.361$ \\
$7^{\text {th }}$ day & $2.037 \pm 0.416$ & $2.043 \pm 0.318^{* *}$ & $1.936 \pm 0.534^{* *}$ \\
$14^{\text {th }}$ day & $1.955 \pm 0.368$ & $1.729 \pm 0.460$ & $1.814 \pm 0.132^{* * \neq}$ \\
$21^{\text {st }}$ day & $2.306 \pm 0.243^{*}$ & $1.889 \pm 0.277^{* *}$ & $1.840 \pm 0.327^{* *}$ \\
$28^{\text {th }}$ day & $2.577 \pm 0.259^{*}$ & $2.190 \pm 0.353^{* *}$ & $1.997 \pm 0.428^{* *, \neq}$ \\
\hline
\end{tabular}

"*" Compared to baseline in intragroup $(\mathrm{p}<0.001)$

"**" Compared to the control group $(\mathrm{p}<0.001)$

" $\neq$ " Compared to the control and tannic acid groups $(\mathrm{p}<0.001)$ 
The levels of 8-OhdG, is an indicator of oxidative DNA damage, assessed according to the time, levels of $8-\mathrm{OHdG}$ was increased in the control and tannic acid groups on the $21^{\text {st }}$ and $28^{\text {th }}$ days $(p<0.001)$. On the other hand, no significant change was determined in caffeic acid group ( $>0.05$, Table 3). Furthermore, 8-OHdG levels of tannic and caffeic acid groups were significantly lower than control group on the $28^{\text {th }}$ day in the intergroup comparisons $(\mathrm{p}<0.002)$.

The comparison of MDA, CoQ10 and 8-OhdG levels changed between baseline and $28^{\text {th }}$ days and between groups showed in Figure 1. MDA, CoQ10 and 8-OHdG levels of caffeic acid group were lower than control group on $28^{\text {th }}$ day, percentage of $64.5 \%, 99.5 \%, 78 \%$ respectively and also decreased in tannic acid group percentage of $58 \%, 99 \%, 31 \%$ respectively. In the tannic acid group, CoQ10 and 8-OHdG levels were less than control group, percentage of $52 \%$ and $68.5 \%$, respectively $(\mathrm{p}<0.05)$ whereas MDA levels did not change significantly.

\section{Discussion}

The development of blood storage system is of great importance owing to the increasing demand of stored blood due to natural calamities and emergencies. Availability of storage raises the question of how long blood products can and should be stored, and how long they are safe and effective (18). During the storage period, it is known that the increase of oxidative stress caused by the formation of reactive oxygen species such as; hydroxyl radical, $\mathrm{H}_{2} \mathrm{O}_{2}$ and superoxide anion radical (19). Free radicals can lead to irreversible damage to the protein and lipids that are found in structure of cell membranes. Thus, membrane integrity is impaired and cell becomes suitable to penetration (20). Plasma is an important component of whole blood and it reflects the changes occurring in whole blood. In plasma most of the cholesterol is esterified. Esterified cholesterol can be converted to unstable lipid hydroperoxides. Lipid peroxidation continues up

Table 3. The effects of tannic and caffeic acid on the level of 8-OHdG

\begin{tabular}{lccc}
\hline \multicolumn{3}{c}{ 8-OHdG $(\mu \mathrm{M})$} \\
\hline Days & Control $($ Mean \pm SE) & Tannic Acid $($ Mean \pm SE) & Caffeic Acid (Mean \pm SE) \\
\hline Baseline & $1.617 \pm 0.242$ & $1.599 \pm 0.328$ & $1.578 \pm 0.266$ \\
7 th day & $1.640 \pm 0.334$ & $1.799 \pm 0.340$ & $1.695 \pm 0.235$ \\
$14^{\text {th }}$ day & $1.802 \pm 0.254$ & $1.890 \pm 0.362$ & $1.913 \pm 0.437$ \\
$21^{\text {st }}$ day & $2.395 \pm 0.446^{*}$ & $2.215 \pm 0.317^{*}$ & $1.982 \pm 0.233$ \\
$28^{\text {th }}$ day & $4.540 \pm 0.303^{*}$ & $2.517 \pm 0.424^{* * * *}$ & $2.213 \pm 0.278^{* *}$ \\
\hline
\end{tabular}

"*" Compared to baseline in intragroup $(\mathrm{p}<0.001)$

"**" Compared to the control group $(\mathrm{p}<0.002)$

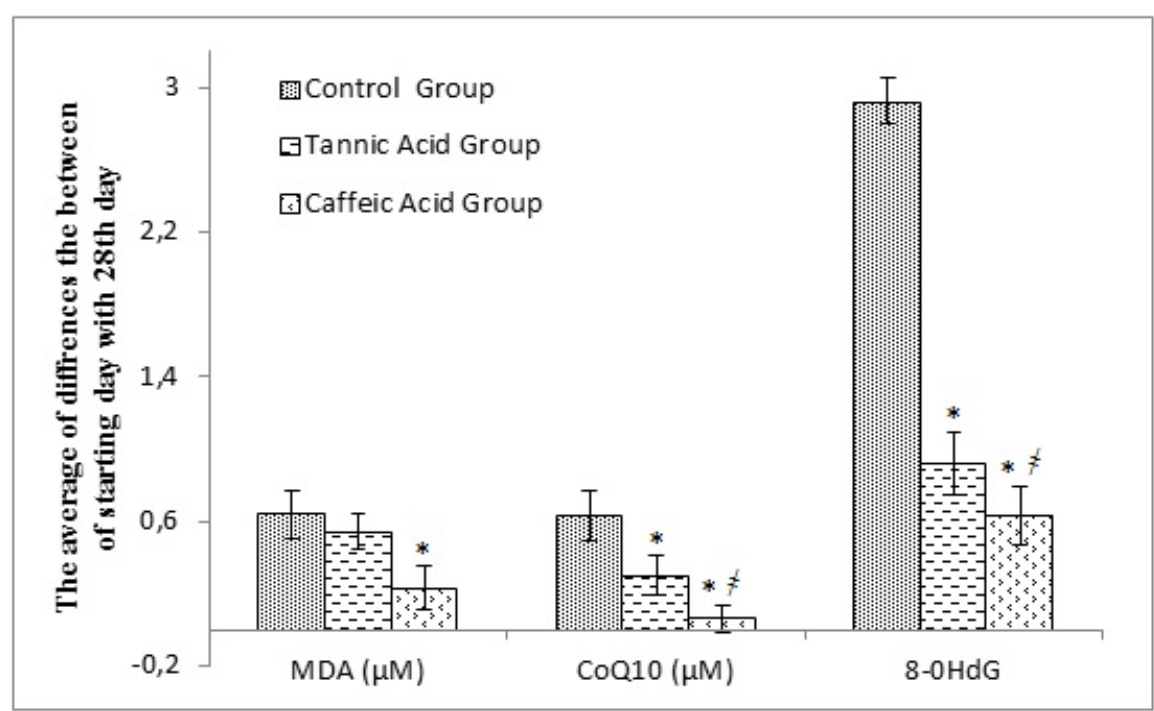

Fig. 1. Comparison of change between inter groups on baseline and $28^{\text {th }}$ day.

"*" Compared to the control group $(\mathrm{p}<0.05)$

" $\neq$ " Compared to the tannic acid group $(\mathrm{p}<0.05)$

East J Med Volume:21, Number:2, April-June/2016 
to the formation of MDA which can modify the proteins and together with membrane lipids, cause membrane damage. Protecting activity of antioxidant defense system may preserve MDA at low level (20-22).

Studies in stored whole blood components play an important role to understand the alteration of oxidative stress during storage (23). Şekeroğlu et. al. (6) reported that MDA levels of erythrocytes increased time-dependently in their study. In the current study we also found that erythrocyte MDA levels increased with storage time in the stored blood. In spite that, adding caffeic acid into the stored blood preserved MDA in low levels compared to the other groups.

Ubiquinol-10 (CoQ10H) a lipid-soluble component of virtually all cell membranes, is an essential electron carrier in the mitochondrial respiratory chain and an important antioxidant in the mitochondrial inner membrane (24). There are two major forms of CoQ10; reduced ubiquinol $(\mathrm{CoQ} 10 \mathrm{H})$ and oxidized (CoQ10). The high rate of $\mathrm{CoQ} 10 / \mathrm{CoQ} 10 \mathrm{H}$ or high level of oxidized CoQ10 is an important indicator in determining mitochondrial membrane damage $(25,26)$. Until now, there are no studies that show the mitochondrial membrane damage in stored blood. In this study the levels of oxidized CoQ10 were increased in the control group time dependently. However, CoQ10 levels of tannic and caffeic acid groups were preserved. These positive results may be caused by the free radicals scavenging activities of tannic and caffeic acid in stored blood.

Reactive oxygen species (ROS) are formed continuously as a consequence of biochemical reactions. ROS can attack any cellular structure or molecule so DNA is considered as an important target. Thus, ROS may cause DNA-protein crosslinks and sugar moiety damage as well as specific chemical modifications of the purine and pyrimidine bases. One of the most abundant oxidative damages to DNA bases is the 8hydroxylation of guanine (27). $8 \mathrm{OHdG}$ is one of the available biomarkers for oxidative DNA damage (28). We could not find any literature that shows oxidative DNA damage in the stored blood. The current study explored the protective effect of caffeic acid against oxidative DNA damage in stored blood and found that in storage with caffeic acid $8 \mathrm{OHdG}$ levels were significantly preserved.

However, the increase in $8-\mathrm{OHdG}$ level was less in the tannic acid group compared to the control group, indicating that tannic acid has partially protective effect against in vitro oxidative DNA damage. Tannic and caffeic acid have effective superoxide anion radical scavenging, total reducing power and metal chelating on ferrous ions activities, these might explain those results.

As a result this study showed that, oxidative stress and lipid peroxidation increased time-dependently in stored blood. Adding tannic acid and caffeic acid into the stored blood protected stored bood against oxidative DNA damage and increased lipid peroxidation especially last period of storage time. In addition, these results also showed that, adding tannic acid and caffeic acid into the stored blood may be retarding the formation of toxic oxidation products, and prolonging the lifespan of stored blood components.

\section{Conflict of Interest: None declared}

Sources for Funding: No funding was obtained for the preparation of this manuscript.

\section{References}

1. Lei C, Xiong LZ. Perioperative Red Blood Cell Transfusion: What We Do Not Know. Chin Med J (Engl) 2015; 128: 2383-2386.

2. Kan bağışında 2015 y1lı başarısı. http://www.kizilay.org.tr/Haber/HaberArsivi Detay/2477; in Turkish.

3. Mustafa I, Al Marwani A, Mamdouh Nasr K, Abdulla Kano N, Hadwan T. Time Dependent Assessment of Morphological Changes: Leukodepleted Packed Red Blood Cells Stored in SAGM. Biomed Res Int 2016; 2016: 4529434.

4. Beutler, E. Preservation and clinical use of erythrocytes and whole blood. In Williams Hematology, Editors; Marshall A. Lichtman, Ernest Betler, Thomas J. Kipps, Uri Selighsohn, Kenneth Kaushansky, Josef T. Prchal. The Mc Graw-Hill Companies 2006; 2159-2163.

5. Huyut Z, Şekeroğlu MR, Balahoroğlu R, Karakoyun T, Çokluk E. The relationship of oxidation sensitivitiy of red blood cells and carbonic anhydrase activity in stored human blood: Effects of certain phenolic compounds. Bio Med Res Int 2016; Article ID 3057384.

6. Şekeroğlu MR, Huyut Z, Him A. The susceptibility of erythrocytes to oxidation during storage of blood: Effect of melatonin and propofol. Clin Biochem 2012; 45: 315-319.

7. Aslan R, Şekeroğlu MR, Tarakçığlu M, Köylü H. Investigation of Malondialdehyde formation and antioxidant enzyme activity in stored blood. Haematol 1997; 28: 233-237.

8. Gülçin İ. Antioxidant properties of resveratrol: a structureactivity insight. Innov Food Sci Emerg 2010; 11: 210-218.

9. Gülçin İ. Antioxidant activity of caffeic acid (3, 4-dihydroxycinnamic acid). Toxicology 2006; 217 : 213-220. 
10. Gülçin I, Huyut Z, Elmastaş M, Y. Aboul-Enein H. Radical scavenging and antioxidant activity of tannic acid. Arab J Chem, King Saud University 2010; 3: 43-53.

11. Chung KT, Wong TY, Wei CI, Huang YW, Lin Y. Tannins and human health: a review. Crit Rev Food Sci 1998; 38: 421.

12. King A, Young G. Characteristics and occurrence of phenolic phytochemicals. J Am Diet Assoc 1999; 99: 213.

13. Laranjinha J, Vieira O, Madeira V, Almeida L. Two related phenolic antioxidants with opposite effects on vitamin $\mathrm{E}$ content in low density lipoproteins oxidized by ferrylmyoglobin: consumption vs. regeneration. Arch Biochem Biophys 1995; 323: 373-381.

14. Khoschsorur GA, Winklhofer-Roob BM, RabP $\mathrm{H}$, et al. Evaluation of a Sensitive HPLC Method for the Determination of Malondialdehyde and Application of the Method to Different Biological Materials. Chromatographia 2000; 52: 181-184.

15. Littarru GP, Mosca F, Fattorini D, Bompadre S, Battino M. Assay of coenzyme Q10 in plasma by a single dilution step. Method Enzymol 2004; 378: 170-176.

16. Kaur H, Halliwell B. Measurement of oxidized and methylated DNA bases by HPLC with electrochemical detection. Biochem J 1996; 318 : 21-23.

17. Tarng DG, Huang TP, Wei YH, et al. 8-hydroxy2 -deoxyguanosine of leukocyte DNA as a marker of oxidative stress in chronic hemodialysis patients. Am J Kidney Dis 2000; 36: 934-944.

18. Hess JR, Greenwalt TG. Storage of red blood cells: new approaches. Transfus Med Rev 2002; 16: 283-295.

19. Vani R, Reddy CS, Devi AS. Oxidative stress in erythrocytes: a study on the effect of antioxidant mixtures during intermittent exposures to high altitude. Int J Biometeorol 2010; 57: 1024-1037.

20. Marjani A, Marodi A, Ghourcaie AB. Alterations in plasma lipid peroxidation and erythrocyte superoxide dismutase and glutathione peroxidase dismutase Enzyme activities during storage of blood. Asian J Biochem 2007; 2: 118-123.

21. Rajashekharaiah V, Abraham Koshy A, Kumar Koushik A, et al. The efficacy of erythrocytes isolated from blood stored under blood bank conditions, Transfus Apher Sci 2012; 47: 359-364.

22. John S, Kale M, Rathore N, Bhatnagar D. Protective effect of vitamin $\mathrm{E}$ in dimethoate and malathion induced oxidative stress in rat erythrocytes. J Nutr Biochem 2001; 12: 500-504.

23. Hsieh C, Ahuja C, Kumari N, Sinha T, Rajashekharaiah V. Curcumin as a modulator of oxidative stress during storage: A study on plasma. Transfus Apher Sci 2014; 50: 288-293.

24. Ostman B, Sjodin A, Michaelsson K, Byberg L. Coenzyme Q10 supplementation and exerciseinduced oxidative stress in humans. Nutrition 2012; 28: 403-417.

25. Stocker R, Bowry VW, Frei B. Ubiquinol-10 Protects Human Low-Density-Lipoprotein More Efficiently against Lipid-Peroxidation Than Does Alpha-Tocopherol. P Natl Acad Sci USA 1991; 88: 1646-1650.

26. Yamashita S, Yamamoto Y. Simultaneous detection of ubiquinol and ubiquinone in human plasma as a marker of oxidative stress. Anal Biochem 1997; 250: 66-73.

27. Loft S, Fischernielsen A, Jeding IB, Vistisen K, Poulsen HE. 8-hydroxydeoxyguanosine as a urinary biomarker of oxidative DNA-damage. J Toxicol Env Health 1993; 40: 391-404.

28. Halliwell B GJ. Free Radicals in Biology and Medicine. Oxford: Oxford Science Publications; 1999. 